RAD Conference Proceedings, vol. 4, pp. 126-131, 2020

ISSN 2466-4626 (online) | DOI: 10.21175/RadProc.2020.27

www.rad-proceedings.org

\title{
DATA ENHANCEMENT OF RADIOECOLOGICAL RESEARCH DURING DRILLING WASTE UTILIZATION TO RECLAMATION MIXTURES
}

\author{
Violetta Kusheeva*, Sergey Ostakh \\ Independent Environmental Expertise Center for Oil and Gas Industry Neftegaz ECO Center, Moscow, Russia
}

\begin{abstract}
The paper highlights topical issues of the drill cuttings radioecological safety assessment in the process of waste management. Particular attention is paid to the necessity for continuous radioecological research and welltimed receipt of their results. The conducted research allows to solve the scientific and practical problem of radioecological studies optimization during management of drilling waste by development of the new methodical approach to their processing and interpretation. The most widespread natural radionuclides $T^{232}, R^{226}, K^{40}$ were selected as the focus group. An example of experimental determining the drill cuttings radiological properties depending on the depth of drilling is given. The results of these works were analyzed using the methods of regression and correlation analysis. The regression dependence of the specific effective radioactivity on the sampling depth for the investigated well is obtained. An approach using the obtained dependences as calibration graphs for a preliminary radiological assessment of drill cuttings of a similar genesis is proposed. The logical-informational model that implements this approach is described. It is shown that the use of the logical-informational model optimizes the decision-making process on the suitability of drill cuttings for their utilization to a useful product - soil-like reclamation mixtures.
\end{abstract}

Keywords: Drill cuttings, drilling waste management, natural radionuclides, radioecological research

\section{INTRODUCTION}

The problem of radioactive contamination during the hydrocarbon raw materials production is widely discussed in Russia, the USA, China and other countries [1].

During the construction of wells in oil and gas fields, a large-tonnage drilling waste - drill cuttings, that need to be utilized or neutralized, is formed. During the application of modern developed technological solutions for the utilization and subsequent use of drilling waste, well-timed and continuous monitoring of their radiation safety is required.

In particular, one of the most resource-efficient methods of drilling waste utilization is production of soil-like recultivation mixtures on their basis. This useful product can be used for the construction of embankments, boarding of technological sites and other earthworks [2]. In the case of a high content of clay materials in drill cuttings, it is possible to use them in biological reclamation to create a potentially fertile layer at well pads.

The ingress of radionuclides into the biosphere has numerous environmental consequences. If natural radionuclides enter into landscapes through the surface, they accumulate in depressions and other accumulative relief elements. Therefore, the popularization and implementation of environmentally and industrially relatively safe, competitive and commercially viable technologies in the field of neutralization and utilization of drilling waste with an increased content of natural radionuclides are classified as promising areas of the environmental policy of oil producing regions in the context of intensive development of the fuel and energy complex [3].

To substantiate chosen method of drill cuttings utilization, timely chemical and analytical studies of drill cuttings are required. The aim of these studies is to determine the content of natural radionuclides and heavy metal compounds in mobile forms [4].

At present, the scientific and practical problem of timely obtaining information about the radiation safety of the disposed drilling waste remains unsolved, due to the existing legislative restrictions on the time of waste accumulation before disposal. The methodological approach proposed in this paper solves this problem by increasing the information content of the conducted radioecological investigations and, as a result, reducing the time spent on such investigations.

Fuel and solid minerals deposits according to the activity of natural radionuclides can be classified into four categories of hazard [5]. Table 1 shows the limit values of effective specific activity of natural radioactive nuclides $\left(\mathrm{A}_{\text {eff }}\right)$ and radiation dose rate $(\mathrm{X})$ for each category. Deposits with pre-clark and clark content of natural radioactive nuclides are classified as safe [6]. This category, almost always, will include deposits located in ultrabasic rocks and quartzites, as well as gypsum, limestone, marble. Deposits in base

*v_kusheeva@mail.ru 
V. Kusheeva and S. Ostakh, Informatization of radioecological research..., RAD Conf. Proc., vol. 4, 2020, 126-131

rocks and sandstones are likely to be classified as potentially hazardous. Dangerous and especially dangerous are deposits of radioactive ores or deposits confined to the areas of radon flows unloading. Safe deposits do not require special studies of their radiation hazard. The conclusion about the degree of danger of other deposits is made on the basis of the radioecological study of the site.

A general tendency for oil and gas production has been revealed: rocks with increased radioactivity are usually formed when drilling horizons with increased salinity [7].

In the exploration and exploitation of hazardous and highly hazardous deposits, special measures are required to ensure the population safety. An individual approach to the selection of drill cuttings utilization technology allows to solve the problem in a comprehensive manner, taking into account the component composition, physical and chemical properties, and the volume of generated drilling waste [8].

Table 1. Classification of deposits by the degree of radiation hazard, corresponding to working conditions

\begin{tabular}{|l|l|l|}
\hline Field category & $\mathrm{A}_{\mathrm{eff}}, \mathrm{Bq} / \mathrm{kg}$ & $\mathrm{X}, \mu \mathrm{R} / \mathrm{h}$ \\
\hline $\begin{array}{l}\text { Extremely } \\
\text { dangerous }\end{array}$ & More than 3300 & More than 350 \\
\hline Dangerous & $1100-3300$ & $115.9-350$ \\
\hline $\begin{array}{l}\text { Potentially } \\
\text { hazardous }\end{array}$ & $101-1101$ & $10.1-116$ \\
\hline Safe & Less than 100 & Less than 10.0 \\
\hline
\end{tabular}

\section{PURPOSE AND OBJECTIVES OF RESEARCH}

The drilling in rocks with increased radioactivity and their removal to the earth surface in the course of drilling operations lead to a complication of the radiation situation on the field. In order to prevent possible radioactive contamination of the area while drilling wells, as well as to timely control the radioactivity of drill cuttings managed to technological sites for utilization, it is recommended to carry out the following types of work:

1. Collection and separate storage of drill cuttings from the interval, including the horizon with ecoanomalous radioactivity;

2. Continuous express radiometric drill cuttings measurement using gamma dosimeters such as MKS01-R, IMD-12, DBG-06T or indicators of gamma radiation SRP-68-01, SRP-88.

3. If an increased background is detected above the natural background of the area by 2 times or more, drill cuttings must be tested and analyzed with increased intensity (gamma spectrometry, chemical analysis of $\mathrm{U}, \mathrm{Th}, \mathrm{Ra}, \mathrm{K})$.

4. After penetration of the supposed anomalous radioactive interval, current gamma-ray logging is required.

Radioecological studies and the corresponding sampling are intended to obtain information about the radiation situation and its changes at the oil and gas facilities with an increased content of natural radionuclides for the purposes of:

- assessment of radiation exposure to workers;

- solving the issues of localization of radioactive contamination, management of the generated drilling waste contaminated with radionuclides;

- implementation of measures to reduce the dose load on people from the identified objects of radiation monitoring;

- development and implementation of measures reducing the negative consequences and harmful effects on the environment.

The purpose of this work is to analyze the information content of the applied radioecological studies of drill cuttings and increase their timeliness in the management of this type of waste.

\section{OBJECT OF STUDY}

Drill cuttings are an aqueous suspension, the solid part of which consists of the rocks material obtained in the result of the well bottom and walls rocks destruction, abrasion of the drill string and well casing. Also drill cuttings usually contain clay minerals (when using clay-based drilling mud or borehole washing with clay drilling fluid).

The environmental threat of drill cuttings depends on both the cuttings and the chemical reagents used in drilling [9].

For the experimental work, drill cuttings from the fields of the West Siberian oil and gas basin were used (Fig. 1). Sampling was carried out at depth intervals from 39 to $3150 \mathrm{~m}$. At a depth of $3150 \mathrm{~m}$, a productive formation was uncovered.

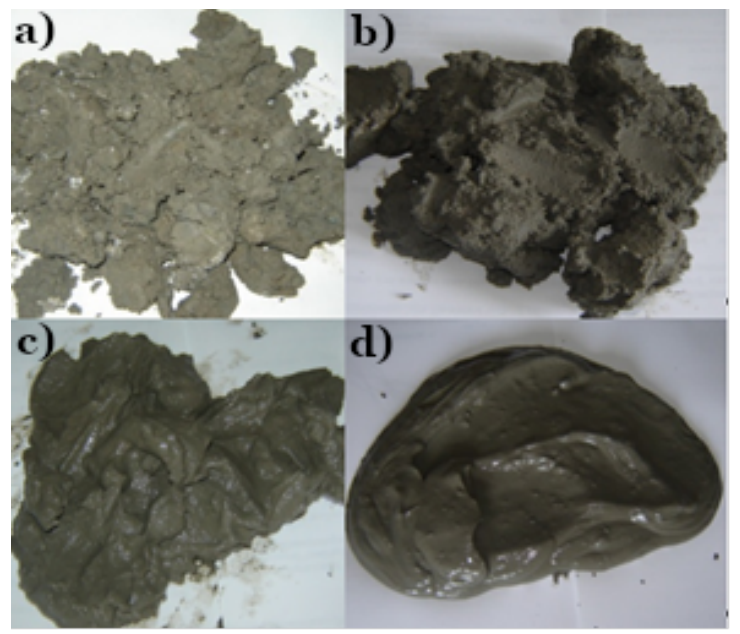

Figure 1. Appearance of the investigated samples of drill cuttings: with varying degrees of humidity: a - 25\%; b - 45\%; c - 65\%; d - 85\%

To ensure drill cuttings environmental safety, they were also subjected to ecotoxicological assessment according to the indicators presented in the table 2 . The given average values of indicators, measured 
V. Kusheeva and S. Ostakh, Informatization of radioecological research..., RAD Conf. Proc., vol. 4, 2020, 126-131

according to the national methods and standards, provide evidence of their toxicological safety of drilling waste for further disposal, which was confirmed by a separate study [10].

Table 2. Ecotoxicological safety assessment of the drill cuttings

\begin{tabular}{|l|l|}
\hline Indicator & Average values \\
\hline Oil and oil products content, \% & $\begin{array}{l}\text { lower than } \\
\text { o,51,25 }\end{array}$ \\
\hline Soluble salt content (chloride type), \% & lower than 5 \\
\hline Soluble salt content (sulpfate type), \% & lower than 3 \\
\hline $\mathrm{pH}$ & 8.0 - 12.0 \\
\hline $\begin{array}{l}\text { Heavy metals: lead, zinc, copper, } \\
\text { nickel, cobalt, iron, manganese, } \\
\text { chromium, etc. }\end{array}$ & $\begin{array}{l}\text { not exceeding } \\
\text { 2-fold MPC } \\
\text { norms }\end{array}$ \\
\hline $\begin{array}{l}\text { Toxicity, hazard class for the } \\
\text { environment (biotesting) }\end{array}$ & IV-V \\
\hline
\end{tabular}

The drill cuttings sampling area is characterized by the occurrence of hydrocarbon deposits in the Cretaceous and Jurassic reservoirs (Figure 2). In general, oil and gas fields occupy most of the territory of the West Siberian oil and gas province and are one of the largest oil-producing regions in the world.

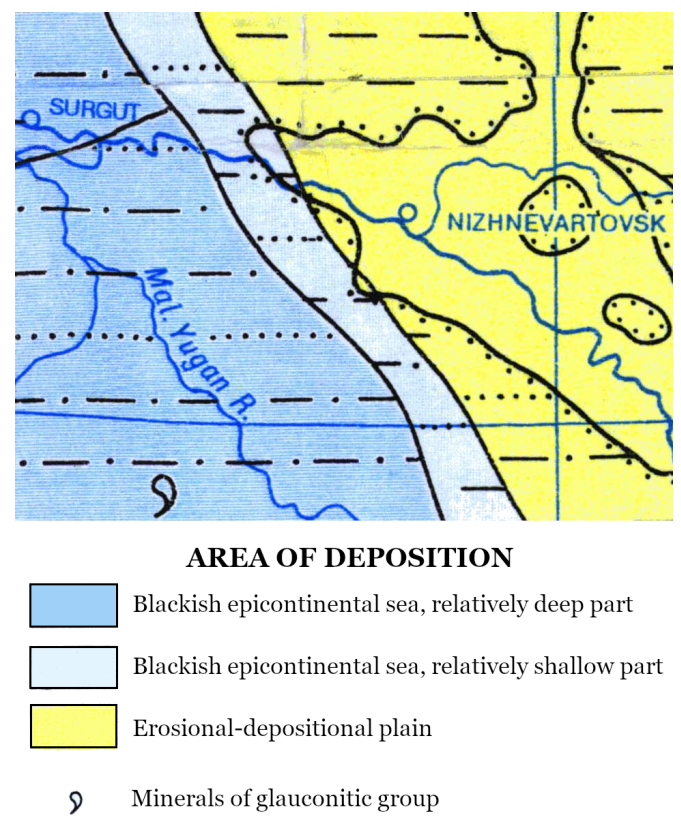

LITHOLOGIES

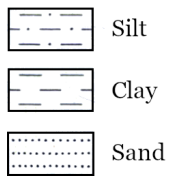

Figure 2. The geological map of the investigated region

\section{RESEARCH METHODS}

The monitored parameters of the radiation environment usually include: effective specific activity of natural radionuclides in industrial waste - Aeff; effective doses of workers exposed to natural sources of radiation in working conditions and levels of exposure to critical groups of the population.

According to modern environmental standards of the Russian Federation, the indicator of radiation safety is the specific effective activity of natural radionuclides - Aeff, which should be less than 370 $\mathrm{Bq} / \mathrm{kg}$. Determination of the specific efficiency of natural radionuclides is carried out in accordance with Russian national standard GOST 30108 "Building materials and products. Determination of the specific effective activity of natural radionuclides" [11].

When carrying out radioecological studies, it is necessary to establish the radionuclide composition of waste and the routes of entry to the environment, taking into account the spatial variability and the geological differentiation of the territory.

The data of long-term studies of drilling waste show that the drilling waste, cuttings and formation water generated during oil production contain mainly $\mathrm{Th}^{232}$, $\mathrm{Ra}^{226}, \mathrm{~K}^{40}$ [12]. This group of natural radionuclides accounts for up to $95 \%$ of the total radioactivity [13]. Therefore, these chemical elements are defined as a focus group limiting the technological possibilities of drilling waste utilization and the field of further application of recultivation mixtures obtained on their basis.

The main radioactive element that accumulates in solid fractions is $\mathrm{K}^{40}$. Moreover, the specific activity of this element can be up to seven times higher than the corresponding value of other natural radionuclides contained in drilling waste.

The activity of gamma-emitting radionuclides in the framework of experimental work was determined according to a certified method developed by the State Scientific Center of Research and Development "Russian Scientific Research Institute of Physical, Technical and Radio Engineering Measurements". The technique is based on the registration of gamma radiation from the object under study using a scintillation spectrometer in a certified measurement geometry and subsequent processing of the measurement information using the specialized software «PROGRESS 5.2».

Five weighted portions were taken to measure radionuclide specific activity of each sample ( 5 -fold repeatability).

The specific activity of radionuclides and specific effective activity were determined using a beta-gamma spectrometric complex with an alpha-scintillation radiometer "Progress-BG + AR" in accordance with the Procedure for measuring the specific activity of radionuclides $\mathrm{Ra}^{226}, \mathrm{Th}^{232}$, $\mathrm{K}^{40}$ in loads using gamma spectrometer SGS-200 NIIRG.

The characteristic of the measurement accuracy is the expanded uncertainty for the coverage factor $\mathrm{k}=2$ $(\mathrm{P}=$ 0.95). The upper limit of the permissible systematic error for this complex is $10 \%$.

To carry out the measurements, containers with a sample of drilling waste were sequentially installed in a radiometric complex. Before starting the measurement, the geometry and the expected radionuclide 
V. Kusheeva and S. Ostakh, Informatization of radioecological research..., RAD Conf. Proc., vol. 4, 2020, 126-131

composition were stated. The accumulation and processing of the instrumental spectrum was carried out by software, taking into account the geometry of measurement chosen by the operator and the library of radionuclides.

When assessing the activity of radionuclides, the specific activity of natural radioactive isotopes A $\left(\mathrm{Ra}^{226}\right), \mathrm{A}\left(\mathrm{Th}^{232}\right)$ and $\mathrm{A}\left(\mathrm{K}^{40}\right)$ were determined (table 3 ). Based on the obtained values, the specific effective activity $\left(\mathrm{A}_{\text {eff }}\right), \mathrm{Bq} / \mathrm{kg}$ - the total activity of natural radionuclides in the material, determined taking into account their biological effect on the human body was calculated according to the formula:

$\mathrm{A}_{\text {eff }}=\mathrm{A}_{\mathrm{Ra}}+1.31 \mathrm{~A}_{\mathrm{Th}}+0.085 \mathrm{~A}_{\mathrm{K}}$

(1)

where $A_{R a}, A_{T h}, A_{K}$ are the specific activities of radium, thorium, potassium, respectively, $\mathrm{Bq} / \mathrm{kg}$.

\section{Processing OF RESEARCH RESUlTS}

Table 3. The results of the natural radionuclides specific activity measurements of the investigated drill cuttings

\begin{tabular}{|l|l|l|l|}
\hline $\begin{array}{l}\text { Sampling } \\
\text { depth, } \mathrm{m}\end{array}$ & $\begin{array}{l}\mathrm{A}(226 \mathrm{Ra}), \\
\mathrm{Bq} / \mathrm{kg}\end{array}$ & $\begin{array}{l}\mathrm{A}(232 \mathrm{Th}), \\
\mathrm{Bq} / \mathrm{kg}\end{array}$ & $\begin{array}{l}\mathrm{A}(40 \mathrm{~K}), \\
\mathrm{Bq} / \mathrm{kg}\end{array}$ \\
\hline 39 & $<8$ & $<8$ & $78.7 \pm 28.7$ \\
\hline 155 & $16.5 \pm 3.9$ & $26.7 \pm 4.6$ & $418 \pm 69$ \\
\hline 218 & $24.2 \pm 3.9$ & $31.2 \pm 4.5$ & $423 \pm 65$ \\
\hline 280 & $<8$ & $<8$ & $149 \pm 31$ \\
\hline 387 & $17.6 \pm 5.9$ & $31.6 \pm 7.4$ & $368 \pm 88$ \\
\hline 574 & $20.9 \pm 4.4$ & $32.2 \pm 5.4$ & $522 \pm 83$ \\
\hline 768 & $18.0 \pm 3.7$ & $32.8 \pm 4.9$ & $561 \pm 81$ \\
\hline 900 & $18.5 \pm 4.3$ & $30.1 \pm 5.5$ & $465 \pm 85$ \\
\hline 1040 & $17.2 \pm 3.9$ & $26.3 \pm 4.8$ & $451 \pm 75$ \\
\hline 1160 & $23.8 \pm 4.5$ & $34.5 \pm 5.5$ & $616 \pm 90$ \\
\hline 1530 & $9.5 \pm 3.4$ & $15.7 \pm 3.9$ & $749 \pm 100$ \\
\hline 2150 & $32.1 \pm 7.6$ & $40.3 \pm 8.8$ & $607 \pm 127$ \\
\hline 2400 & $26.3 \pm 4.9$ & $38.1 \pm 5.9$ & $735 \pm 104$ \\
\hline 2560 & $19.1 \pm 4.3$ & $29.3 \pm 5.3$ & $571 \pm 88$ \\
\hline 3080 & $27.1 \pm 4.5$ & $36.9 \pm 5.3$ & $659 \pm 91$ \\
\hline 3110 & $35.3 \pm 5.5$ & $43.5 \pm 6.3$ & $877 \pm 119$ \\
\hline 3150 & $28.4 \pm 4.7$ & $38.2 \pm 5.5$ & $626 \pm 90$ \\
\hline & & & \\
\hline
\end{tabular}

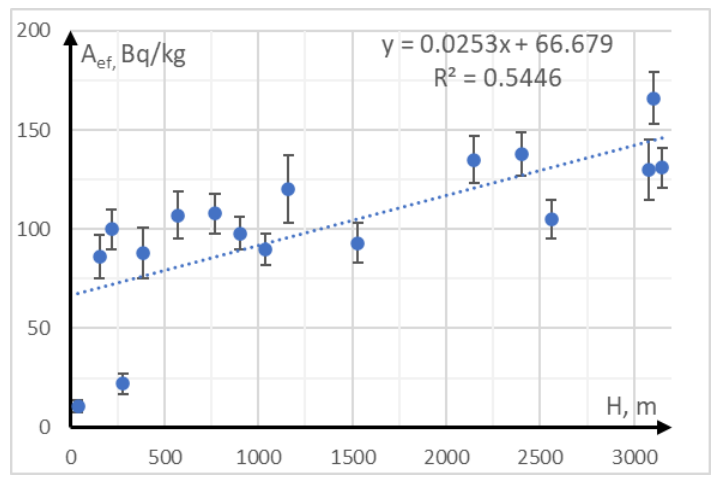

Figure 3. Values of specific effective activity of drill cuttings (Aeff) at different sampling depths (h) and the result of linear approximation of the obtained experimental data
The results obtained for determining the specific effective activity depending on the sampling depth, taking into account the accuracy limits, are shown in Fig. 3. The result of linear approximation of the dependence turned out to be unsatisfactory: the coefficient of determination $\mathrm{R}^{2}=0.5446$.

To obtain an adequate regression dependence, a mathematical analysis of the data on the specific effective activity depending on the sampling depth was performed using the methods of regression and correlation analysis. The least squares method was chosen as the approximation method to obtain an approximate regression equation of the form:

$$
y=f(x)
$$

where y - values of specific effective activity of drill cuttings, Bq / kg, $\mathrm{x}$ - sampling depth, $\mathrm{m}$.

Factors: $\mathrm{x}^{\mathrm{n}}$, where $\mathrm{n}=\mathrm{o} \ldots 5, \cos (\mathrm{x}), \sin (\mathrm{x}), \ln (\mathrm{x})$ $\mathrm{e}^{\mathrm{x}}$ were investigated as hypothetical factors of the regression model. To determine the type of the regression equation, the procedure of successive exclusion of insignificant factors was carried out.

The hypothesis of significance was confirmed only for the factors $\mathrm{x}^{0}$ and $\ln (\mathrm{x})$. The coefficients of the regression equation for these factors showed good conditioning. The resulting regression equation is following:

$$
\mathrm{y}=25.395 \ln (\mathrm{x})-69.025
$$

It is characterized by the highest value of the coefficient of determination $\mathrm{R}^{2}=0.6737$ and is presented as a trend in Figure 4a. The result of linearization of the obtained dependence upon transition to semi-logarithmic coordinates is shown in Figure $4 b$.

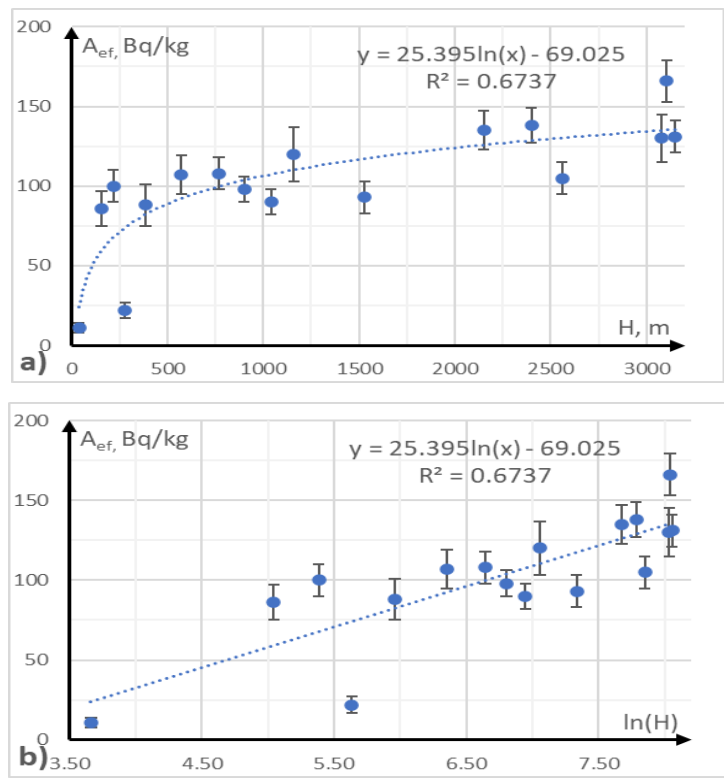

Figure 4. The result of the logarithmic approximation of the dependence: specific effective activity of drill cuttings - depth: $\mathrm{a}$ - in conventional coordinates, b - in semi-logarithmic coordinates 
V. Kusheeva and S. Ostakh, Informatization of radioecological research..., RAD Conf. Proc., vol. 4, 2020, 126-131

The use of a semi-logarithmic grid is convenient from a practical point of view for improvement of visualization when comparing data from different years, as well for simplification of data processing of variables taking large range of values. Semi-logarithmic coordinates form the infological semantics of the designed database. This kind of data processing makes it possible to obtain a clearly pronounced break in the course of the curve and, therefore, to more clearly determine the range of values of the specific effective activity of drill cuttings at the given design drilling depths.

The resulting dependence can be used as a calibration graph for a preliminary assessment of the radiological properties of drill cuttings formed during drilling in similar geological conditions.

It should also be noted that regardless to the depth of drill cuttings sampling, the specific efficiency of radionuclides in all samples is less than $370 \mathrm{~Bq} / \mathrm{kg}$. This allows to utilize them with production of soil-like reclamation mixtures without time limiting restrictions on the radiation factor.

\section{DISCUSSION OF RESEARCH RESULTS}

The nature of the change in the natural radioactivity of the cuttings, depending on the depth, can have a different form, depending on the properties of the formations being drilled and lithological differences. Therefore, it is not always possible and appropriate to conduct a regression analysis. However, the obtained experimental dependences can be used as calibration graphs when drilling other wells located in similar geological conditions, and therefore having a identical genesis of drill cuttings.

There is a known method of binding drill cuttings to the section of the well [14], which consists in comparing the data of gamma-ray logging along the wellbore with measurements of the natural radioactivity of the cuttings, which is a product of destruction of the same rocks. This makes it possible to refer cuttings samples to depth by combining the depths of the characteristic marks on the gamma-ray $\log$ and on the natural gamma-activity diagram of the cuttings.

Within the framework of this study, a solution to the inverse problem is proposed. For a known well drilling depth and, consequently, a certain genesis of drill cuttings it is assumed to determine the approximate values of the specific effective radioactivity of the newly generated drill cuttings using the earlier obtained calibration curves in a continuous mode.

When analyzing and interpreting information according to the formed optimal plan, it is necessary to have appropriate metainformation models to substantiate organizational and technical solutions for radioecological research. It is possible to formalize these activities using a logical information model (hereinafter - LIM), which offers end-to-end traceability of infological components.

The creation and maintenance of a database within the unified LIM (Figure 5) of radioecological studies of drill cuttings will provide a timely radiation assessment of the formed drill cuttings, which is necessary for making an environmentally oriented management decision on the direction of this type of waste management.

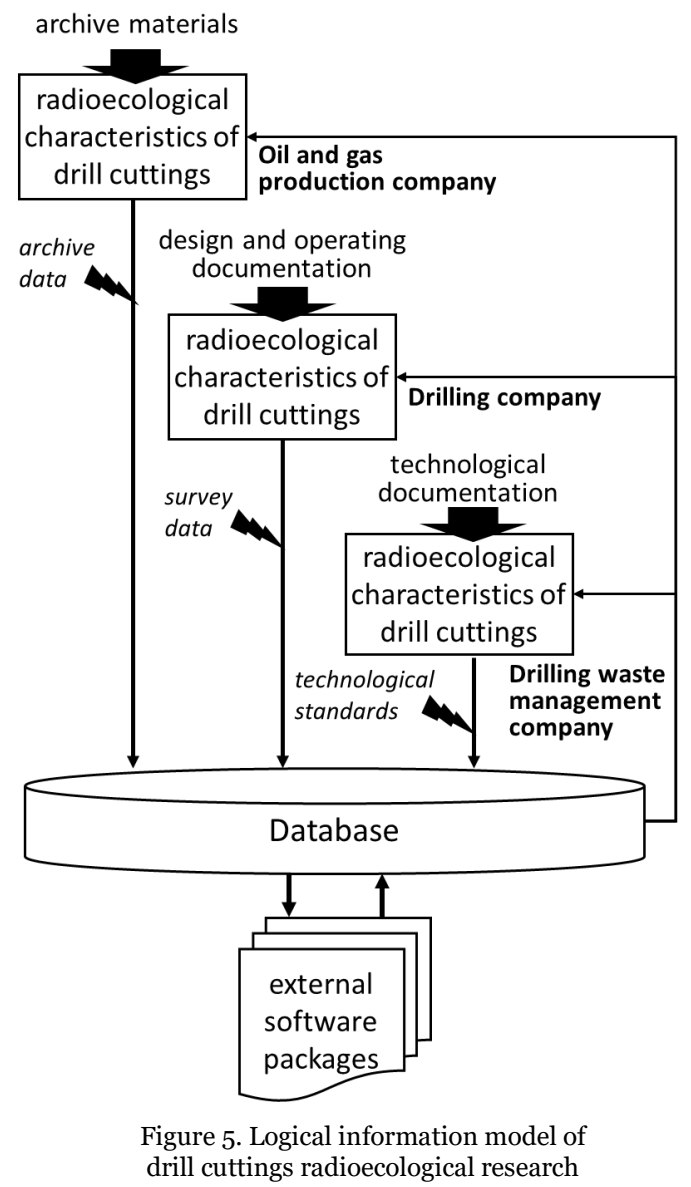

LIM includes the following components: information (database), logical (heuristic algorithm for choosing indicators), software (internal and external program complexes), which allows to symbolically express the relationship in a visual form.

LIM allows to select the required indicators from the database and to apply this information basis for several (rather than one) tasks, some of which will be created in the future.

\section{CONCLUSION}

The developed information-analytical approach will ensure the reliability, comparability and timeliness of the radiation safety assessment of the drilling waste, and also optimizes the decision-making process about its suitability for utilization with production of soil-like recultivation mixtures on their basis.

Thus, the use of express methods for determining the effective radiation activity of natural radionuclides in combination with the proposed logicalinformational approach will make it possible to 
V. Kusheeva and S. Ostakh, Informatization of radioecological research..., RAD Conf. Proc., vol. 4, 2020, 126-131

optimize radioecological studies for managing the processes of drilling waste management and to reduce the time of accumulation of this waste before utilization.

The developed approach to the radioecological data processing makes it possible to increase the information content of the obtained data, to increase the area of their demanded use and to substantiate the safety of drill cuttings from a single oil and gas region.

\section{REFERENCES}

1. E. R. Landa, "Naturally occurring radionuclides from industrial sources: characteristics and fate in the environment," Radioactivity in the Environment, vol. 10, pp. 211-237, 2007 https://doi.org/10.1016/S1569-4860(06)10010-8

2. M. D. A. Sharif, N. V. R. Nagalakshmi, S. S. Redd, "Drilling waste management and control the effects," J. Adv. Chem. Eng., vol. 7, no. 1, 2017. https://doi.org/10.4172/2090-4568.1000166

3. С. В. Мещеряков, С. В. Остах, О.С. Остах, Д. И. Рогожин, "Инжиниринговая интерактивная система по обезвреживанию нефтесодержащих отходов, загрязненных природными радионуклидами," Безопасность труда в промышленности, № 9, С. 46-51, 2017.

(S.V. Meshcheryakov, S.V. Ostakh, O.S. Ostakh, D.I. Rogozhin, "Interactive engineering system for the neutralization of oily waste contaminated with natural radionuclides," Labor Safety in Industry, vol. 9, p. 46-51, 2017.)

Retrieved from:

https://www.elibrary.ru/download/elibrary 299917 $80 \quad 37741525 . \mathrm{pdf}$

4. S. I. Onwukwe, M. S. Nwakaudu, "Drilling wastes generation and management approach," International Journal of Environmental Science and Development, vol. 3, no. 3, pp. 252-257, 2012. Retrieved from:

http://www.ijesd.org/papers/226-D598.pdf

5. В. А. Галактионов, В.Г. Журавлев, И.В. Павлова, B.А. Домаренко "Ранжирование техногенного радионуклидного загрязнения по критериям оценки радиоэкологического состояния при строительстве Альконского горнометаллургического комбината," Материалы V Международной конференции. ФГАОУ ВО "Национальный исследовательский Томский политехнический университет,” с. 172-175, 2016. (V. Galaktionov, V. Juravlev, I. Pavlova, V. Domarenko "Ranging of technogenic radionuclide pollution on estimation criteria of radioecological condition for Elkon mining metallurgical plant construction," Materials of the $V$ International Conference. FGAOU VO "National Research Tomsk Polytechnic University”, pp. 172-175, 2016)

6. M. F. Attallah, H. M. Abdelbary, E. A. Elsofany, Y. T. Mohamed, M. M. Abo-Aly, "Radiation safety and environmental impact assessment of sludge TENORM waste produced from petroleum industry in Egypt," Process Safety and Environmental Protection, vol. 142, pp. 308-316, 2020. https://doi.org/10.1016/j.psep.2020.06.012

7. F. Moatar, S. R. Shadizadeh, A. R. Karbassi et al., "Determination of naturally occurring radioactive materials (NORM) in formation water during oil exploration," J. Radioanal. Nucl. Chem., vol. 283 pp. 3-7, 2010.

https://doi.org/10.1007/s10967-009-0001-2

8. С. В. Мещеряков, С. В. Остах, А. В. Сушкова, О.С. Остах, "Алгоритмический подход к процессам обращения с отходами бурения," Экология и промышленность России, № 10 (21), C. 9-13, 2017.

(S. V. Meshcheryakov, S. V. Ostakh, A. V. Sushkova, O. S. Ostakh, "Algorithmic Approach to the Processes of Drilling Waste Management," Ecology and Industry of Russia, vol. 10, no. 21, pp. 9-13, 2017.) https://doi.org/10.18412/1816-0395-2017-10-9-13

9. A. R. Ismail, A. H. Alias, W. R. W. Sulaiman, M. Z. Jaafar, I. Ismail "Drilling fluid waste management in drilling for oil and gas wells," Chemical Engineering Transactions, vol. 56, pp. 1351-1356, 2017. https://doi.org/10.3303/CET1756226

10. O. Ostakh, E. Uzyakova, N. Grechishcheva, V. Kusheeva "Ecotoxicological assessment of soil-like mixtures made of drill cuttings," Journal of Engineering, Design and Technology, vol. ahead-ofprint, no. ahead-of-print, 2021.

https://doi.org/10.1108/JEDT-07-2020-0310

11. ГОСТ 30108-94, "Материалы и изделия строительные. Определение удельной эффективной активности естественных радионуклидов,” М.: Стандартинформ, с. 16, 2007.

(GOST 30108-94, "Building materials and products. Determination of the specific effective activity of natural radionuclides," M.: Standartinform, p. 16 , 2007.)

http://docs.cntd.ru/document/gost-30108-94

12. J. Jónás, J. Somlai, A. Csordás, E. Tóth-Bodrogi, T. Kovács, "Radiological survey of the covered and uncovered drilling mud depository," Journal of Environmental Radioactivity, vol. 188, pp. 30-37, 2018.

https://doi.org/10.1016/j.jenvrad.2017.10.020

13. А. В. Безденежных, О. С. Остах, С. В. Остах, $\begin{array}{ll}\text { В. Л. Заворотный, } & \text { В. С. Столбовой, }\end{array}$ "Радиационно-химическая характеристика буровых шламов Западной Сибири и модернизация системы обращения с отходами бурения," Экология и промышленность России, T. 24, № 9, C. 16-21, 2020 .

(A. V. Bezdenezhnykh, O. S. Ostakh, S. V. Ostakh, V. L. Zavorotny, V. S. Stolbovoy, "Radiationchemical characteristics of drilling cuttings from Western Siberia and modernization of the drilling waste management system," Ecology and Industry of Russia, vol. 24, no. 9, pp. 16-21, 2020) https://doi.org/10.18412/1816-0395-2020-9-16-21

14. В.Ф. Горбунов, В. М. Кузьмин, И. М. Плюснин, Б. А. Терентьев, Ю. С. Шимелевич, "Способ привязки бурового шлама к разрезу скважины,” Авторское свидетельство SU 898372 A1, 15.01.1982. Заявка № 2574891 от 30.01.1978.

(V. F. Gorbunov, V. M. Kuzmin, I. M. Plyusnin, B. A. Terentyev, Yu. S. Shimelevich, "Method of attaching drill cuttings to the well section," Inventor's certificate SU 898372 A1, 15.01.1982, Application No. 2574891 dated 01/30/1978.)

Retrieved from:

https://www.elibrary.ru/download/elibrary 399939 18 26203133.pdf 